\title{
ANNUAL CUMULATIVE OF SOIL CARBON CHANGE IN Pinus merkusii PLANTATION IN CIANTEN, WEST JAVA
}

\author{
Harris Herman Siringoringo and Chairil Anwar Siregar ${ }^{1}$
}

\begin{abstract}
Important carbon storage in a forest vegetation includes below ground carbon storage and above ground carbon storage. Carbon storage under the ground is higher than that above ground, so that soils are critical both as a source and sink of carbon. The main objective of this research is to examine the annual changes of soil carbon storage from year 2001 to year 2003 in the permanent plots of an experimental plantation (new plantation established in the year 2001) and in the permanent plots of control plot/baseline (young secondary forest), in Cianten Experimental Site, Bogor, West Java. Soil carbon content at $0-30 \mathrm{~cm}$ depth for 0 year old, 1 year old and 2 year old plantations are $4.14-9.35 \%$, $4.088 .83 \%$ and $3.04-7.61 \%$, respectively. Soil carbon content at control plot for 2001, 2002 and 2003 are $1.86-5.75 \%, 2.32-5.79 \%$ and $2.05-4.84 \%$, respectively. Bulk density at $0-30 \mathrm{~cm}$ soil depth for 0 year old, 1 year old, and 2 year old plantations are $0.38-0.5 \mathrm{mg} / \mathrm{m}^{3}, 0.38-0.52 \% \mathrm{mg} / \mathrm{m}^{3}$ and $0.32-0.5$ $\mathrm{mg} / \mathrm{m}^{3}$, respectively. Bulk density at control plot for 2001,2002 and 2003 are $0.47-0.63 \mathrm{mg} / \mathrm{m}^{3}, 0.43$ $0.6 \mathrm{mg} / \mathrm{m}^{3}$ and $0.41-0.55 \mathrm{mg} / \mathrm{m}^{3}$, respectively. The cumulative soil carbon stock of Pinus merkusii plantation is somewhat higher than that of baseline in Cianten Experimental Site, Bogor, West Java.
\end{abstract}

Keywords: Soil carbon, bulk density, cumulative

\section{INTRODUCTION}

Main issue among environmental observers nowadays is still focusing on a dominant green house gas, carbon dioxide. The effect of this carbon on global climate change has caused natural disaster on each part of the world (increasing temperature, forest fire, hurricane, increasing sea level). The problem is becoming more serious and great concern has been realistically reflected on UNFCCC Conference, Rio de Janeiro, December 1992, and the Kyoto Protocol, Japan, December 1997, in which Indonesian Government signed the Convention.

The result of the International Convention eventually offers the ultimate International project on sink program as one of the alternative in controlling carbon emission. Furthermore, this sink program will be included in the clausul of Clean Development Mechanism (CDM). CDM is a very important provision of the Kyoto Protocol in which developing countries with tropical rain forest are to be involved in an effort to decrease carbon emission through the development of carbon sink, biodiversity and sustainable forest management.

\footnotetext{
${ }^{1}$ Forest and Nature Conservation Research and Development Center, Bogor
} 
In the $7^{\text {th }}$ Conference of the Parties (COP7) meeting, the participating countries agreed to include afforestation activities into CDM to promote the expansion of industrial tree plantation in the devastated areas of developing countries in the tropics, which were once covered with thick tropical rain forest.

In a forest system, particularly in tree biomass and soil there are two major carbon pools. Therefore for estimating carbon fixation by tree plantation establishment and its change over stand age, it is essential to know the change in carbon storage in a soil together with carbon in biomass. However, it would be easy to understand the carbon fixing potential above the ground in the forest by monitoring the growth of trees. On the other hand, it would be difficult to estimate the carbon fixing potential under the ground in the forest.

Carbon storage under the ground is no less than that above the ground. On a global scale, soils are critical both as a source and a sink of carbon. With a global stock about $1500 \mathrm{Pg}$ of soil organic carbon (SOC), soils hold 2.1 times as much carbon as the atmosphere and 2.7 times more than standing vegetation (Metting et al., 1998). Therefore, it is important to study the carbon fixing potential under the ground in the forest in order to grasp the forest function on carbon fixing, which is recognized as the contribution to the mitigation of global warming. The amount of carbon storage in the soil and its annual changes/transition will be examined in this research.

The main objective of this research was to examine the annual changes of soil carbon from year 2001 to year 2003 in the permanent plots of an experimental plantation (new plantation established in the year 2001) and in the permanent plots of control/baseline (young secondary forest), in Cianten Experimental Site, Bogor, West Java.

\section{MATERIALAND METHODS}

\section{A. Soil Sampling Site Description}

Experimental site was established in plantation area of Pinus merkusii located in Block 24B, RPH Cianten, BKPH Leuwiliang, KPH Bogor, Perum Perhutani, Unit III West Java. According to Siringoringo et al. (2003), the soil classification is Dystric Nitisol (fine, mixed, active, isohyperthermic, Typic Hapludult), (USDA-NRCS, 1998).

\section{B. Sampling for Soil Carbon Storage}

Soil sampling at 0-30 $\mathrm{cm}$ depth was done in respective plot one time each year regularly, started in December 2001(soon after land preparation) until 2003. For 0-30 cm depth sampling, soil samples were taken from the soil layers of $0-5 \mathrm{~cm}, 5-10 \mathrm{~cm}, 10-20 \mathrm{~cm}$ and $20-30$ $\mathrm{cm}$ depths, respectively. Procedure of soil sampling was done based on method described by Hatori (2003).

\section{Analytical Method and Calculation of Soil Carbon Storage}

1. Bulk density (BD) was measured using a $100 \mathrm{cc}\left(20 \mathrm{~cm}^{2} \times 5 \mathrm{~cm}\right)$ core cylinder for sampling. The sampling was performed with four replications for each soil layer, and the four cylinder samples taken from each soil layer were mixed together to prepare one composite sample for each layer. 
2. Total carbon content was determined by dry-combustion method using a NC analyzer (Sumigraph NC-900, Sumitomo Chemicals).

3. The amount of carbon stored in each soil layer was calculated by multiplying carbon concentration, bulk density and thickness of each layer.

\section{Experimental Design and Statistical Analysis}

Experimental design used for soil study was completely randomized block design (CRBD) with five (5) replications for permanent control (baseline) plot and four (4) replications for permanent plantation plots. Land preparation was started in December 2001. P. merkeusii seedlings were planted in early January 2002, with spacing of $2 \mathrm{~m}$ by $3 \mathrm{~m}$.

Plot setting used for soil sampling at plantation and control plots was as follows :

1. Plantation plot: 4 plots ( $30 \mathrm{~m} \times 20 \mathrm{~m}$ each) were set in the slashed land.

2. Control plot/baseline: 5 plots $(10 \mathrm{~m} \times 10 \mathrm{~m}$ each) were set in the young secondary forest.

Carbon change on each depth and plot was evaluated with analysis of variance (ANOVA) using JMP Start Statistics (Sall et al., 2005). All possible pairs of means were compared in a One Way ANOVA, and test procedure was conducted using Tukey-Kramer Honestly Significant Difference (HSD).

\section{RESULTS AND DISCUSSION}

\section{A. Soil Carbon Content}

The results of annual soil carbon content of Cianten experimental site are summarized in Table 1 covering mean value, standard deviations (SD), and coefficient of variation (CV) in each soil layer from surface down to $30 \mathrm{~cm}$ depth. The average of soil carbon content in $0-5$ $\mathrm{cm}, 5-10 \mathrm{~cm}, 10-20 \mathrm{~cm}$, and $20-30 \mathrm{~cm}$ depths of plantation plots and baseline plots in Cianten was shown in Figure 1. The level of soil carbon decrease tremendously as the soil depth increase across all year of observations and land use type.

There was no annual significant change in soil carbon content based on the time of examination neither on baseline plots nor on plantation plots in the year 2001 to year 2003. Figure 1 also illustrates comparison between carbon content of Pinus merkusii plantations plot and that of baseline plot. Pinus merkusii plantations plot seemed to have higher soil carbon content in $0-30 \mathrm{~cm}$ depth than that of baseline plot. This finding is probably due to the difference of patches of the soil with different characteristics between baseline plot and Pinus merkusii plantation plot, so scattering of data was very wide. As shown in Table 1, coefficient of variation $(\mathrm{CV})$ of soil carbon content for baseline plot is more scattered than that of plantation.

Coefficient of variation of Pinus merkusii plantation for soil carbon content was in a range between 10 and $16 \%$ for 0 - year old plantation, between 20 and $27 \%$ for 1 year old plantation, and between 2 and $25 \%$ for 2 years old plantation. Whereas, coefficient of variation of baseline plot dominated by the young secondary forest between $38 \%$ and $72 \%$ examined in the year 2001, between 35 and 48\% examined in the year 2002, and between 40 and $73 \%$ examined in the year 2003 . 
Table 1. Annual soil carbon content (\%) results from baseline plots and plantation plots in Cianten from year 2001 to year 2003

\begin{tabular}{|c|c|c|c|c|c|}
\hline Plot & Depth $(\mathrm{cm})$ & $\begin{array}{c}\text { Year of } \\
\text { observation }\end{array}$ & $\begin{array}{l}\text { Mean } \\
(\mathrm{C} \%)\end{array}$ & SD & $\begin{array}{l}\text { CV } \\
\%\end{array}$ \\
\hline \multirow{3}{*}{$\begin{array}{l}\text { Baseline (young } \\
\text { secondary forest) }\end{array}$} & $\begin{array}{c}0-5 \\
5-10 \\
10-20 \\
20-30\end{array}$ & $\begin{array}{l}2001 \\
2001 \\
2001 \\
2001\end{array}$ & $\begin{array}{l}5.75 \\
4.01 \\
2.54 \\
1.86\end{array}$ & $\begin{array}{l}2.2 \\
2.9 \\
1.32 \\
1.21\end{array}$ & $\begin{array}{l}0.38 \\
0.72 \\
0.52 \\
0.65\end{array}$ \\
\hline & $\begin{array}{c}0-5 \\
5-10 \\
10-20 \\
20-30\end{array}$ & $\begin{array}{l}2002 \\
2002 \\
2002 \\
2002 \\
\end{array}$ & $\begin{array}{l}5.79 \\
4.76 \\
3.31 \\
2.32 \\
\end{array}$ & $\begin{array}{l}2.13 \\
1.65 \\
1.6 \\
0.81 \\
\end{array}$ & $\begin{array}{l}0.37 \\
0.35 \\
0.48 \\
0.35 \\
\end{array}$ \\
\hline & $\begin{array}{c}0-5 \\
5-10 \\
10-20 \\
20-30\end{array}$ & $\begin{array}{l}2003 \\
2003 \\
2003 \\
2003 \\
\end{array}$ & $\begin{array}{l}4.84 \\
3.44 \\
2.45 \\
2.05\end{array}$ & $\begin{array}{l}1.93 \\
2.16 \\
1.67 \\
1.5 \\
\end{array}$ & $\begin{array}{l}0.4 \\
0.63 \\
0.68 \\
0.73 \\
\end{array}$ \\
\hline \multirow{3}{*}{$\begin{array}{l}\text { Plantation } \\
\text { (established in the } \\
\text { year 2001) }\end{array}$} & $\begin{array}{c}0-5 \\
5-10 \\
10-20 \\
20-30\end{array}$ & $\begin{array}{l}2001 \\
2001 \\
2001 \\
2001\end{array}$ & $\begin{array}{l}9.35 \\
7.61 \\
5.78 \\
4.14\end{array}$ & $\begin{array}{l}0.96 \\
0.89 \\
0.82 \\
0.68\end{array}$ & $\begin{array}{l}0.1 \\
0.12 \\
0.14 \\
0.16\end{array}$ \\
\hline & $\begin{array}{c}0-5 \\
5-10 \\
10-20 \\
20-30\end{array}$ & $\begin{array}{l}2002 \\
2002 \\
2002 \\
2002\end{array}$ & $\begin{array}{l}8.83 \\
7.67 \\
5.71 \\
4.08\end{array}$ & $\begin{array}{l}1.76 \\
1.64 \\
1.37 \\
1.1 \\
\end{array}$ & $\begin{array}{l}0.2 \\
0.21 \\
0.24 \\
0.27\end{array}$ \\
\hline & $\begin{array}{c}0-5 \\
5-10 \\
10-20 \\
20-30\end{array}$ & $\begin{array}{l}2003 \\
2003 \\
2003 \\
2003\end{array}$ & $\begin{array}{l}7.61 \\
7.19 \\
5.26 \\
3.04\end{array}$ & $\begin{array}{l}1.53 \\
1.79 \\
0.69 \\
0.06\end{array}$ & $\begin{array}{l}0.2 \\
0.25 \\
0.13 \\
0.02\end{array}$ \\
\hline
\end{tabular}

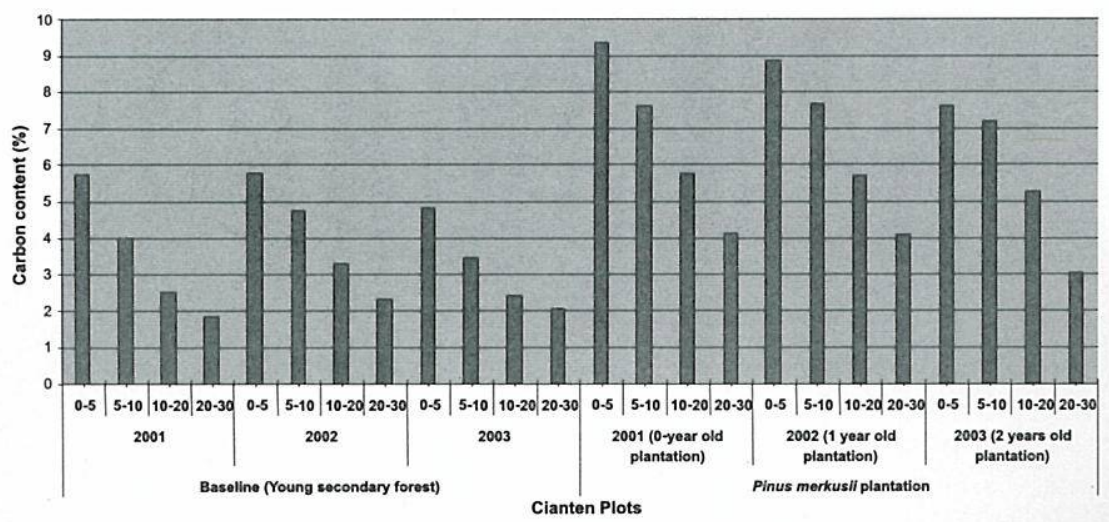

Figure 1. Comparison of annual soil carbon content of baseline plot and newly established Pinus merkusii plantation plot among different depths in Cianten from year 2001 2003 


\section{B. Bulk Density}

The results of annual soil bulk density value of Cianten are summarized in Table 2, covering mean value, standard deviations (SD), and coefficient of variation (CV) in each soil layer from the surface down to $30 \mathrm{~cm}$ depth. The soil bulk density average in $0-5 \mathrm{~cm}, 5-10 \mathrm{~cm}, 10-20 \mathrm{~cm}$, and 20$30 \mathrm{~cm}$ depths of plantation plot and baseline plot in Cianten experimental plot was shown in Figure 2. The magnitudes of soil bulk density increase considerably as the soil depth increase across all year of observations and land use type.

Table 2. Annual soil bulk density of baseline plots and newly established Pinus merkusii plots in Cianten from year 2001 to year 2003

\begin{tabular}{|c|c|c|c|c|c|}
\hline Plot & $\begin{array}{l}\text { Depth } \\
(\mathrm{cm})\end{array}$ & $\begin{array}{c}\text { Year of } \\
\text { observation }\end{array}$ & $\begin{array}{c}\text { Mean } \\
\left(\mathrm{BD}, \mathrm{g} / \mathrm{m}^{3}\right)\end{array}$ & SD & CV \\
\hline \multirow{3}{*}{$\begin{array}{l}\text { Baseline/Control } \\
\text { plot (young } \\
\text { secondary forest) }\end{array}$} & $\begin{array}{c}0-5 \\
5-10 \\
10-20 \\
20-30\end{array}$ & $\begin{array}{l}2001 \\
2001 \\
2001 \\
2001\end{array}$ & $\begin{array}{l}0.47 \\
0.57 \\
0.6 \\
0.63\end{array}$ & $\begin{array}{l}0.07 \\
0.15 \\
0.09 \\
0.07\end{array}$ & $\begin{array}{c}0.16 \\
0.25 \\
0.16 \\
0.1\end{array}$ \\
\hline & $\begin{array}{c}0-5 \\
5-10 \\
10-20 \\
20-30\end{array}$ & $\begin{array}{l}2002 \\
2002 \\
2002 \\
2002\end{array}$ & $\begin{array}{c}0.43 \\
0.51 \\
0.59 \\
0.6\end{array}$ & $\begin{array}{l}0.07 \\
0.11 \\
0.15 \\
0.07\end{array}$ & $\begin{array}{l}0.16 \\
0.21 \\
0.26 \\
0.12 \\
\end{array}$ \\
\hline & $\begin{array}{c}0-5 \\
5-10 \\
10-20 \\
20-30\end{array}$ & $\begin{array}{l}2003 \\
2003 \\
2003 \\
2003\end{array}$ & $\begin{array}{l}0.41 \\
0.49 \\
0.52 \\
0.55\end{array}$ & $\begin{array}{l}0.08 \\
0.1 \\
0.13 \\
0.13\end{array}$ & $\begin{array}{c}0.19 \\
0.2 \\
0.25 \\
0.23\end{array}$ \\
\hline \multirow{3}{*}{$\begin{array}{l}\text { Plantation } \\
\text { (established in the } \\
\text { year 2001) }\end{array}$} & $\begin{array}{c}0-5 \\
5-10 \\
10-20 \\
20-30 \\
\end{array}$ & $\begin{array}{l}2001 \\
2001 \\
2001 \\
2001 \\
\end{array}$ & $\begin{array}{l}0.38 \\
0.44 \\
0.47 \\
0.5\end{array}$ & $\begin{array}{l}0.04 \\
0.03 \\
0.04 \\
0.04 \\
\end{array}$ & $\begin{array}{l}0.11 \\
0.06 \\
0.08 \\
0.08 \\
\end{array}$ \\
\hline & $\begin{array}{c}0-5 \\
5-10 \\
10-20 \\
20-30\end{array}$ & $\begin{array}{l}2002 \\
2002 \\
2002 \\
2002 \\
\end{array}$ & $\begin{array}{l}0.38 \\
0.44 \\
0.49 \\
0.52 \\
\end{array}$ & $\begin{array}{l}0.09 \\
0.05 \\
0.04 \\
0.03 \\
\end{array}$ & $\begin{array}{l}0.23 \\
0.1 \\
0.08 \\
0.07 \\
\end{array}$ \\
\hline & $\begin{array}{c}0-5 \\
5-10 \\
10-20 \\
20-30\end{array}$ & $\begin{array}{l}2003 \\
2003 \\
2003 \\
2003\end{array}$ & $\begin{array}{l}0.32 \\
0.41 \\
0.5 \\
0.37\end{array}$ & $\begin{array}{c}0.02 \\
0.06 \\
0.03 \\
0.003\end{array}$ & $\begin{array}{l}0.08 \\
0.14 \\
006 \\
0.01\end{array}$ \\
\hline
\end{tabular}


There is no annual significant change of soil bulk density value from year 2001 to the year 2003 (three time examination) for baseline plot and plantation plot. In most soil profiles the value of bulk density was the lowest in the uppermost soil layer due possibly to stronger and stable development of soil structure facilitated by higher organic contents, higher root development and higher soil faunal activity. However, it may not be reasonable to ascribe the different patterns in bulk density among the plots to the land use history for agriculture, which may different from place to place, judging from the remarkably large difference in the value not only in the shallower parts but also in the deeper parts of soil. Consequently, the inter-plot difference in bulk density might be due to the inherent characteristics of the respective soils. According to Ohta and Effendy (1992), bulk densities of ultisols in East Kalimantan are strongly controlled by their clay contents. The different patterns in bulk density found between Pinus merkusii plantation plots and baseline plots of Cianten might have been caused also possible differences in clay content among the soils.

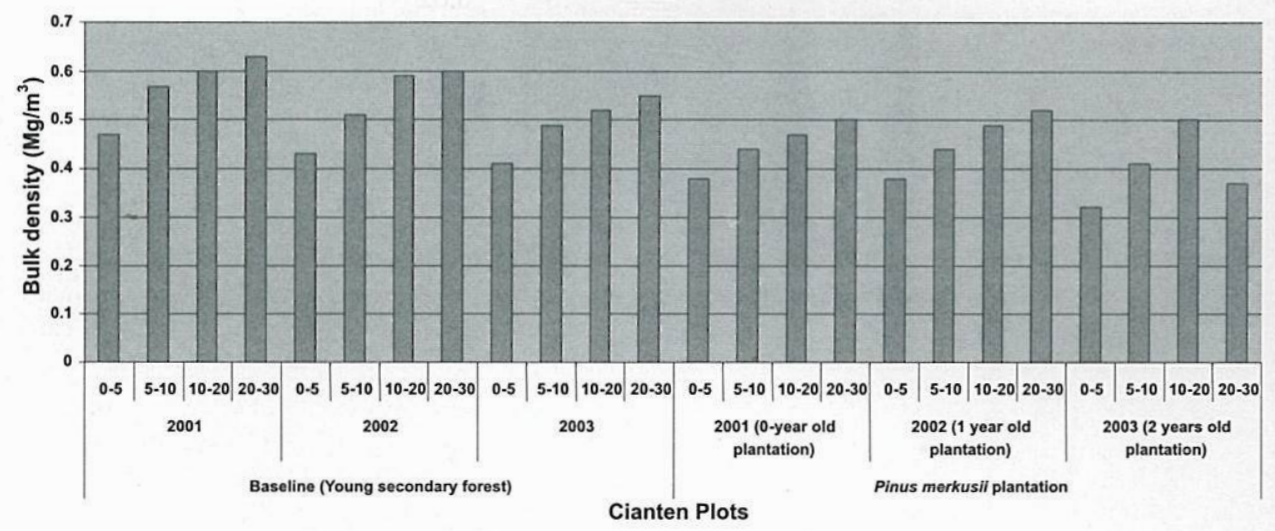

Figure 2. Comparison of annual bulk density of baseline plots and newly established Pinus merkusii plantation plot in Cianten among different depths from year 2001 to 2003

Coefficient of variation of Pinus merkusii plantation for bulk density was in a range between 6.0 and $11 \%$ for 0 - year old plantation, between 7.0 and $23 \%$ for 1 year old plantation, and between 1 and $14 \%$ for 2 years old plantation. Whereas, coefficient of variation of baseline dominated by the young secondary forest between 10 and $25 \%$ examined in the year 2001 , between 12 to $21 \%$ examined in the year 2002 , between 19 to $25 \%$ examined in the year 2003. In addition, there were no consistent patterns in change of CV for bulk density with depth except for relatively higher CVs in the uppermost soil layers in the respective soil profile reflecting higher heterogeneity in soil physical properties in surface soils. However, the range of the CV showed a tendency to be different among the plots, and was relatively higher in the baseline plot annually from the year 2001 to the year 2003. Although the reason of which is not clearly known, it is probably due to the different inherent characteristics among the soils. 


\section{Carbon Stock}

The results of annual carbon stock value of Cianten are summarized in Table 3 covering mean value, standard deviations (SD), and coefficient of variation (CV) in each soil layer down to $30 \mathrm{~cm}$ depth.

Table 3. Annual carbon stock of baseline plots and newly established Pinus merkusii plantation plots in Cianten from year 2001 to year 2003

\begin{tabular}{|c|c|c|c|c|c|}
\hline Plot & $\begin{array}{l}\text { Depth } \\
(\mathrm{cm})\end{array}$ & $\begin{array}{c}\text { Year of } \\
\text { observation }\end{array}$ & $\begin{array}{l}\text { Mean } \\
\text { (Carbon } \\
\text { Stock } \\
\text { Ton/ha) }\end{array}$ & SD & CV \\
\hline \multirow{3}{*}{$\begin{array}{l}\text { Baseline/Control } \\
\text { Plot (young } \\
\text { Secondary } \\
\text { forest) }\end{array}$} & $\begin{array}{c}0-5 \\
5-10 \\
10-20 \\
20-30\end{array}$ & $\begin{array}{l}2001 \\
2001 \\
2001 \\
2001\end{array}$ & $\begin{array}{l}14.4 \\
11.65 \\
16.02 \\
12.1\end{array}$ & $\begin{array}{l}3.94 \\
6.76 \\
7.29 \\
6.56 \\
\end{array}$ & $\begin{array}{l}0.27 \\
0.58 \\
0.45 \\
0.54\end{array}$ \\
\hline & $\begin{array}{c}0-5 \\
5-10 \\
10-20 \\
20-30 \\
\end{array}$ & $\begin{array}{l}2002 \\
2002 \\
2002 \\
2002 \\
\end{array}$ & $\begin{array}{l}13.94 \\
12.44 \\
19.34 \\
14.54\end{array}$ & $\begin{array}{c}3.51 \\
3.43 \\
7.89 \\
5.0\end{array}$ & $\begin{array}{l}0.25 \\
0.28 \\
041 \\
0.34\end{array}$ \\
\hline & $\begin{array}{c}0-5 \\
5-10 \\
10-20 \\
20-30\end{array}$ & $\begin{array}{l}2003 \\
2003 \\
2003 \\
2003 \\
\end{array}$ & $\begin{array}{l}12.21 \\
9.85 \\
14.62 \\
13.02 \\
\end{array}$ & $\begin{array}{l}3.81 \\
5.26 \\
8.59 \\
8.42 \\
\end{array}$ & $\begin{array}{l}0.31 \\
0.53 \\
0.59 \\
0.65 \\
\end{array}$ \\
\hline \multirow{3}{*}{$\begin{array}{l}\text { Plantation } \\
\text { (established in } \\
\text { the year 2001) }\end{array}$} & $\begin{array}{c}0-5 \\
5-10 \\
10-20 \\
20-30 \\
\end{array}$ & $\begin{array}{l}2001 \\
2001 \\
2001 \\
2001 \\
\end{array}$ & $\begin{array}{l}22.39 \\
21.23 \\
32.44 \\
23.94 \\
\end{array}$ & $\begin{array}{l}4.2 \\
3.13 \\
3.15 \\
1.98 \\
\end{array}$ & $\begin{array}{l}0.19 \\
0.15 \\
0.1 \\
0.08\end{array}$ \\
\hline & $\begin{array}{c}0-5 \\
5-10 \\
10-20 \\
20-30\end{array}$ & $\begin{array}{l}2002 \\
2002 \\
2002 \\
2002\end{array}$ & $\begin{array}{l}21.93 \\
20.09 \\
33.24 \\
24.36 \\
\end{array}$ & $\begin{array}{l}2.74 \\
2.8 \\
6.19 \\
4.51 \\
\end{array}$ & $\begin{array}{l}0.13 \\
0.14 \\
0.19 \\
0.19 \\
\end{array}$ \\
\hline & $\begin{array}{c}0-5 \\
5-10 \\
10-20 \\
20-30\end{array}$ & $\begin{array}{l}2003 \\
2003 \\
2003 \\
2003\end{array}$ & $\begin{array}{l}17.97 \\
18.7 \\
30.68 \\
17.42 \\
\end{array}$ & $\begin{array}{l}2.79 \\
3.82 \\
3.31 \\
0.31 \\
\end{array}$ & $\begin{array}{c}0.16 \\
0.2 \\
0.11 \\
0.02 \\
\end{array}$ \\
\hline
\end{tabular}


The carbon stock in $0-5 \mathrm{~cm}, 5-10 \mathrm{~cm}, 10-20 \mathrm{~cm}$, and $20-30 \mathrm{~cm}$ depths of plantation plot and baseline plot in Cianten experimental plot was shown in Figure 3. The amount carbon stock of the plantation plot in $0-5 \mathrm{~cm}, 5-10 \mathrm{~cm}, 10-20 \mathrm{~cm}, 20-30 \mathrm{~cm}$ depths in different ages which was observed in the year 2001, 2002, and 2003 was $22.39-4.2$ ton/ha, $21.23-3.13$ ton/ha, $32.44-3.15$ ton/ha, and 23.94 - 1.98 ton/ha after land preparation (year 2001);21.93 - 2.74 ton/ha, $20.09-2.8$ ton/ha, $33.24-6.19$ ton/ha, $24.36-4.51$ ton/ha in one year old plantation (year 2002) ; 17.97 - 2.79 ton/ha, 18.7 - 3.82 ton/ha, 30.68 - 3.31 ton/ha, 17.42 0.31 ton/ha in 2 years old plantation (year 2003), respectively.

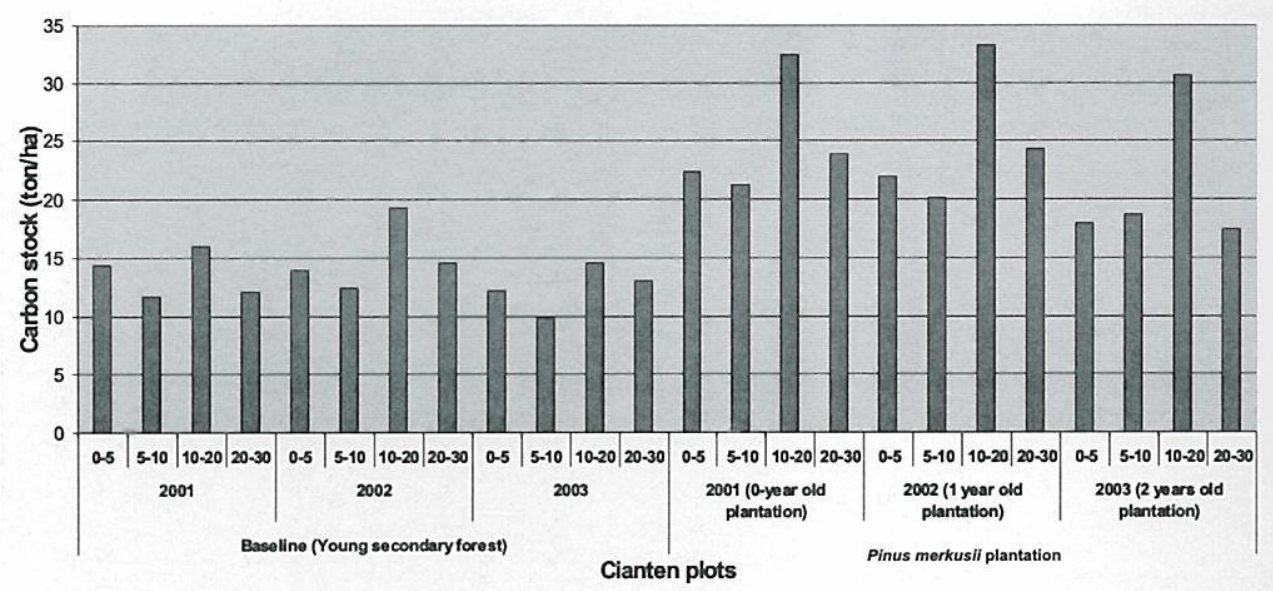

Figure 3. Comparison of annual carbon stock of baseline plots and newly established Pinus merkusii plantation plot in Cianten among different depths from year 2001 to 2003

While the carbon stock of the baseline plot in $0-5 \mathrm{~cm}, 5-10 \mathrm{~cm}, 10-20 \mathrm{~cm}, 20-30 \mathrm{~cm}$ depths in different ages was 14.4 - 3.94 ton/ha, 11.65 - 6.76 ton/ha, 16.02 - 7.29, 12.1 - 6.56 ton/ha in the year 2001; $13.94-3.51$ ton/ha, $12.44-3.43$ ton/ha, $19.34-7.89$ ton/ha, 14.54 5.0 ton/ha in the year 2002; and 12.21 - 3.81ton/ha, 9.85 - 5.26 ton/ha, $14.62-8.59$ ton/ha, $13.02-8.42$ ton/ha, respectively. There is no annual significant change of amount of soil carbon stock from the year 2001 to the year 2003 on the baseline plots and the plantation plots.

\section{Cumulative Carbon Stock}

The results of annual cumulative carbon stock of Cianten experimental site are summarized in Table 4 covering mean value, standard deviations (SD), and coefficient of variation (CV) in each soil layer down to $30 \mathrm{~cm}$ depth. Comparison of annual cumulative soil carbon stock between baseline and plantation plot in Cianten from year 2001 to year 2003 are shown in Figure 4. 
The result of analysis of variance for cumulative soil carbon stock for the baseline plot/control plot in Cianten experimental plot in the year 2001, 2002, 2003 are shown in Table 5. The cumulative carbon stock in $0-30 \mathrm{~cm}$ soil layers was $54,17 \mathrm{ton} / \mathrm{ha}, 60,26 \mathrm{ton} / \mathrm{ha}$, 49,7 ton/ha for permanent baseline plot observed in the year 2001, 2002, 2003, respectively. The comparison of cumulative carbon stock mean value of baseline based on annual observation, from the year 2001 to year 2003, did not differ significantly (one-way ANOVA, P $>0.05)$.

Table 4. Annual cumulative carbon stock of baseline plots and newly established Pinus merkusii plantation plots in Cianten from year 2001 to year $2003^{?}$

\begin{tabular}{|l|c|c|c|c|c|}
\hline Plot & $\begin{array}{c}\text { Depth } \\
\text { (cm) }\end{array}$ & $\begin{array}{c}\text { Year of } \\
\text { observation }\end{array}$ & $\begin{array}{c}\text { Mean of } \\
\text { carbon } \\
\text { stock } \\
\text { (ton } / \text { ha })\end{array}$ & SD & CV \\
\hline \multirow{5}{*}{ Baseline/Control } & $0-5$ & 2001 & 14.4 & 3.94 & 0.27 \\
plot (young & $0-10$ & 2001 & 26.05 & 5.42 & 0.42 \\
secondary forest) & $0-20$ & 2001 & 42.07 & 6.01 & 0.43 \\
& $0-30$ & 2001 & 54.17 & 6.04 & 0.45 \\
\cline { 2 - 6 } & $0-5$ & 2002 & 13.94 & 3.51 & 0.25 \\
& $0-10$ & 2002 & 26.38 & 3.36 & 0.25 \\
& $0-30$ & 2002 & 45.72 & 6.01 & 0.43 \\
\cline { 2 - 6 } & $0-5$ & 2002 & 60.26 & 5.52 & 0.37 \\
\hline \multirow{5}{*}{ Plantation } & $0-10$ & 2003 & 12.21 & 3.81 & 0.31 \\
(established in & $0-20$ & 2003 & 22.06 & 4.51 & 0.41 \\
the year 2001) & $0-30$ & 2003 & 36.68 & 6.1 & 0.5 \\
& $0-5$ & 2001 & 49.7 & 6.52 & 0.52 \\
\hline & $0-10$ & 2001 & 43.62 & 3.48 & 0.19 \\
& $0-20$ & 2001 & 78.06 & 6.15 & 0.16 \\
& $0-30$ & 2001 & 100 & 5.38 & 0.22 \\
\cline { 2 - 6 } & $0-5$ & 2002 & 21.93 & 2.74 & 0.13 \\
& $0-10$ & 2002 & 42.02 & 2.75 & 0.13 \\
& $0-20$ & 2002 & 75.26 & 7.18 & 0.29 \\
\cline { 2 - 6 } & $0-30$ & 2002 & 99.2 & 6.48 & 0.26 \\
\hline & $0-5$ & 2003 & 17.97 & 2.79 & 0.16 \\
& $0-10$ & 2003 & 36.67 & 2.46 & 0.12 \\
& $0-20$ & 2003 & 67.35 & 6.26 & 0.27 \\
& $0-30$ & 2003 & 84.77 & 5 & 0.22 \\
\hline
\end{tabular}




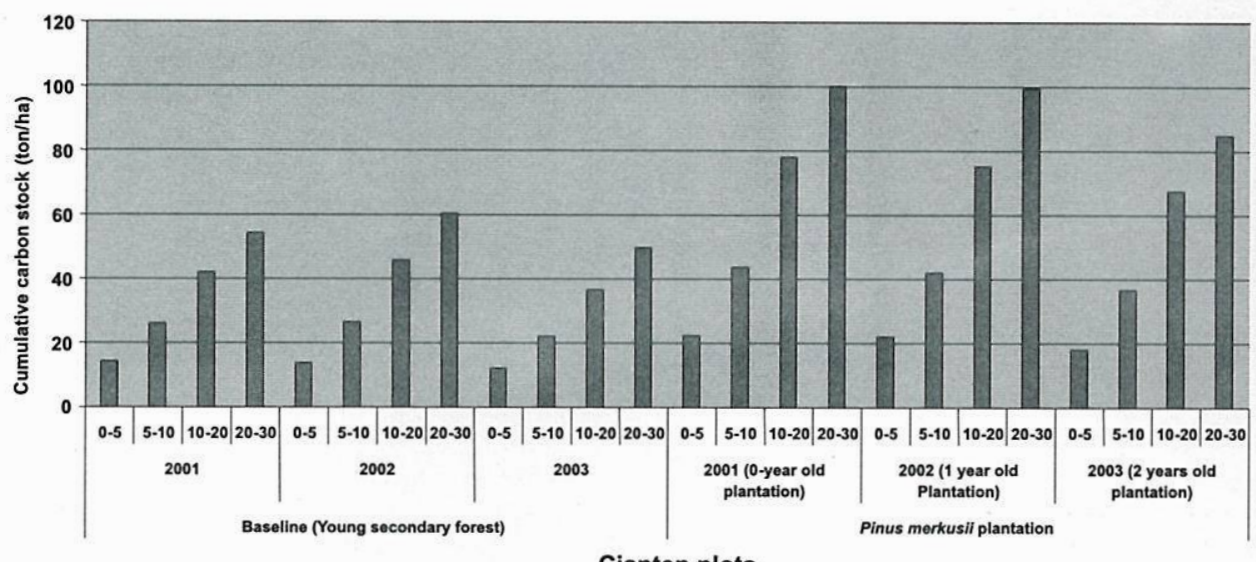

Figure 4. Comparison of annual cumulative carbon stock of baseline plots and newly established Pinus merkusii plantation plots in Cianten Experimental Site among different depths from year 2001 to year 2003

Table 5. Analysis of variance of cumulative carbon stock for baseline by the year

\begin{tabular}{|c|c|c|c|c|c|}
\hline Source & DF & Sum of Squares & Mean of Square & F Ratio & Prob $>$ F \\
\hline Year & 2 & 86.3171 & 43.16 & 0.3443 & 0.7187 \\
\hline Block & 4 & 4243.57 & 1060.89 & 8.4642 & 0.0057 \\
\hline Error & 8 & 1002.708 & 125.34 & & \\
\hline Corrected Total & 14 & 5332.596 & & & \\
\hline
\end{tabular}

Mean while, the cumulative soil carbon stock for $0,1,2$ year-old plantation (observed in the year 2001, 2002, 2003) was 100 ton/ha, 99,2 ton/ha, 84,77 ton/ha, respectively. The comparison of mean value of cumulative soil carbon stock of the Pinus merkusii plantation from year 2001 to year 2003 was done and the difference is not significant (one-way ANOVA, $P>0.05)$. The results of the analysis of variance for cumulative soil carbon stock for the plantation by the year are shown in Table 6 .

Table 6. Analysis of variance of soil carbon stock cumulative for plantation by the year

\begin{tabular}{|c|c|c|c|c|c|}
\hline Source & DF & Sum of Square & Mean of Square & F Ratio & Prob $>$ F \\
\hline Year & 2 & 21.7272 & 10.864 & 0.0648 & 0.9379 \\
\hline Block & 3 & 1133 & 377.67 & 2.2523 & 0.1827 \\
\hline Error & 6 & 1006.08 & 167.68 & & \\
\hline Corrected total & 11 & 2160.81 & & & \\
\hline
\end{tabular}


The comparison of mean value of cumulative soil carbon stock between plantation and baseline across all year of observation was done, and the difference is highly significant (oneway ANOVA, $\mathrm{P}<0.01)$. The result of the analysis of variance for cumulative soil carbon stock between plantation plots and baseline plots are shown in Table 7 . The cumulative carbon stock occurred in the pines plantation appears to be tremendously higher than that in the baseline. Note that the cumulative carbon stock occurring in baseline ranged from 50 to 60 ton/ha, meanwhile the cumulative carbon stock resulting in pine plantation site ranged from 85 to 100 ton/ ha from 0 to $30 \mathrm{~cm}$ soil depth.

Table 7. Variance analysis of cumulative soil carbon stock by plots (baseline and plantation plots

\begin{tabular}{|c|c|c|c|c|c|}
\hline Source & DF & Sum of Square & Mean of Square & F Ratio & Prob $>$ F \\
\hline Plot & 1 & 14518.1 & 14518.1 & 48.4363 & $<.0001$ \\
\hline Error & 25 & 7493.402 & 299.7 & & \\
\hline Corrected Total & 26 & 22011.51 & & & \\
\hline
\end{tabular}

\section{CONCLUSION}

1. There is no significant annual changes of soil carbon content, soil bulk density, soil carbon stock, and cumulative soil carbon stock in both the Pinus merkusii plantation plot and baseline plot from year 2001 to year 2003.

2. The cumulative soil carbon stock of Pinus merkusii plantation is much higher than that of baseline in Cianten Experimental Site, Bogor, West Java.

3. The cumulative carbon stock in $0-30 \mathrm{~cm}$ soil layers was $54.17 \mathrm{ton} / \mathrm{ha}, 60.26 \mathrm{ton} / \mathrm{ha}$, and 49.7 ton/ha for permanent baseline plot in the year 2001, 2002, 2003, respectively. Meanwhile, the soil carbon stock cumulative was 100 ton/ha, 99.2 ton/ha, 84.77 ton/ha for 0 -year old plantation, 1-year old plantation, 2-years old plantation, respectively.

\section{REFERENCES}

Hatori, H. 2003. Soil analysis. A report of Carbon Fixing Forest Management Project between Japan International Cooperation Agency and Forestry Research and Development Agency. Ministry of Forestry, Indonesia.

Metting, F.B., J.L. Smith and J.S. Amthor. 1998. Science needs and new technology for soil carbon sequestration. In N.J. Rosenberg, R.C. Izaurralde and E. L Malone (Eds.), Carbon Sequestration In Soils. Battelle Press. Colombus, Ohio.

Ohta, S. and Effendi. 1992. Ultisols of "Lowland Dipterocarp Forest" in East Kalimantan, Indonesia, I. Morphology and physical properties, Soil Sci Plant Nutr. No. 38. 
Siringoringo, H.H., C.A. Siregar and H. Hatori. 2003. Analysis of soil carbon accumulation of Pinus merkusii plantation in Cianten, West Java. Bulletin Penelitian Hutan, No. 634: 93 $-104$.

Sall, J., L. Creighton and A. Lehman. 2005. JMP Start Statistics. A Guide to Statistics and Data Analysis Using JMP and JMP in Software. Thomson Learning Academic Resource Center. Third Edition.

USDA-NRCS.1998. Keys To Soil Taxonomy. $8^{\text {th }}$ Edition. USDA, Washington,DC. 